\title{
Sinafricology: A Paradigm Shift from African Studies to Chinese Africology/Africanology in Chinese Academia
}

\author{
TALING TENE RODRIGUE（大灵・德内•罗德里格） \\ $\mathrm{PhD}$. from Cameroon is a Research Fellow at the Institute of African Studies, Zhejiang Normal University \\ (China) \\ Vice-Director of the Center for Francophone Studies, Institute of African Studies, Zhejiang Normal University. \\ 688 Yingbin road Jinhua Zhejiang, China; Zip: 321004
}

\begin{abstract}
Study Focus: The present article advocates an "Afrocentric study of Africa" in Chinese academia, examines the concepts of "Afrocentricity", "Africology", "Africanology" and finally proposes "Sinafricology" as a new the terminology expressing a Paradigm shift from the existing traditional African Studies to a sort of Chinese Africology/Africanology that should be promoted in Chinese Academia.

Methodology: The content of this paper relies primarily on written documents (including books, scientific journals, articles, and official reports) most of which are available online as well as on the author's teaching experience in Chinese and African Universities.

Findings:

1) The hundred years' narrow and inert framework of "Sino-Western duality thinking" instilled into the Chinese scholarship circles by the Western ideological imperialism of the $19^{\text {th }}$ and $20^{\text {th }}$ centuries have somehow overshadowed African Studies in the today's Chinese Academia.

2) With "Afrocentricity" as a theoretical foundation, "Africology" \& "Africanology" reflect the historical specificities and cultural responses of Africans from Mainland and Diasporas with regards to the universal cultural imperialism that Africa throughout history has been confronted with.

3) An "Afrocentric study of Africa" in Chinese academia is a must. For, they will be no deep understanding of the "Africana phenomena" by the Chinese scholarship without the thorough exploration of the central concepts of "Afrocentricity", "Africology", and "Africanology".

4) "Sinafricology" as a sort of Chinese "Africology"/"Africanology", reflects a new horizon of African Studies in Chinese Academia with Africans as subjects rather than objects, while embracing the Chinese characteristics of modern academia. "Sinafricology" can achieve its goals through a 5-layers' approach, namely the Theoretical, Methodological, Content Knowledge, Institutional and Governmental layers.

Conclusion \& Suggestions:

Based on the aforementioned findings, this article holds that an "Afrocentric study of Africa" is of an urgent need for the domestic development of contemporary Chinese social sciences. The mainstream ideologies of Africanists of African origin should be the core lenses through which any in-depth study of Africa should be undertaken. Therefore, a Paradigm Shift from African Studies to Chinese Africology/Africanology or "Sinafricology" in Chinese Academia is strongly suggested, "Sinafricology" will aim at providing its learners with an Afrocentric approach of the African reality while embracing the Chinese characteristics of modern academia.
\end{abstract}

Keywords: Afrocentricity, Africology, "Africanology", "Sinafricology”, Chinese Academia

DOI: $10.7176 / \mathrm{JEP} / 11-9-02$

Publication date:March $31^{\text {st }} 2020$

\section{Introduction}

African studies in general terms could be understood as the socio-cultural study of the continent of Africa. It's a field of study that uses the traditional methodology of humanities and social sciences to examine the continent's history, culture, politics, economy, languages, religion, etc. With the "the people of Africa" as the main object of study, the field focuses on the continent's cultures and societies rather than the continent's nature (geology, geography, zoology...). Unlike as in the United States of America's education where there is a well-defined academic curriculum of "African Studies" that critically examines the cultures, societies and political economies of people of African origin and descent and exposes students to historical texts and literature, modern social issues, philosophical questions and political crises through an African-centered lens known as Africology, many countries of the world still lag behind when it comes to a proper insertion of African studies in their academic curriculum and so fail to provide students with a well-rounded knowledge of Africa. As a result, they rely on resources and knowledge provided by international institutions where African voices remain unheeded. The Chinese academia for example, despite its growing number of institutions and research centers devoted on the study of Africa in recent years, not only still lack a holistic discipline conception of African studies, but also lack a comprehensive education curriculum (at least at university level) that could provide students with a more profound knowledge of Africa through an African-centered lens. As Chinese interests are growing on the continent, a better understanding 
of African peoples and societies by the Chinese scholarship is of premium necessity. Meanwhile, the Chinese involvement in the continent's development and economic growth have arisen Africa's interest for China, and so created avenues for the African scholarship to devote more attention to the study of China. Fortunately, given the political will to cooperate displayed by Chinese and African leaderships through platforms such as FOCAC (Forum on China-Africa Cooperation), it is ideal time for both sides to put in place proper education reforms that will propel the study of each other at a higher level.

\section{Afrocentricity: A Philosophical Crystallization of a Holistic Africa-centered perspective}

As a field of knowledge taught and researched at college or university level in modern academia, African Studies is recognized by many academic institutions and journals around the world. However, as scholastic debates on African Studies have long been dominated by Eurocentric views, it is important above all to examine the field from a perspective in which Africans are subjects rather than objects. In this approach, Africans (mainland and diasporan) are the storytellers of the African realities. This African-centered approach embraces the philosophical concept of Afrocentricity as its theoretical foundation. Prof. Molefi Kete Asante, one of the leading promoters of the theory expounds a clear definition of the term Afrocentricity in his book "The Afrocentric Idea". For him, "Afrocentricity is the most complete philosophical totalization of the African being at-the-center of his or her existence. It is not merely an artistic or literary movement. Not only is it an individual or collective quest for authenticity, but it is above all the total use of the method to affect psychological, political, social, cultural, and economic change. The Afrocentric idea is beyond decolonizing the mind."(Asante, 1987) In the above definition, Prof. Asante presents the Afrocentric perspective as an alternative cosmology that critiques the Eurocentric hegemonic ideology in the social sciences, professions, and humanities. The ontological idea behind the concept is that of an African consciousness being the center of African existentialism. This is a powerful move with regards to today's modern academia where Africa remains the backdrop of all-azimuths ideologies, thoughts and beliefs that have been influencing the continent during the past fifteen centuries, and that has somehow shaped the today's African society. Afrocentricity is not to be mistaken or confused with Afrocentrism which is negatively labeled by some western scholars such as Robert Todd Carroll, Banner-haley C.P, Clarence E. Walker(Banner \& Walker, 2003 ), etc. as "Eurocentrism with Black face", "Black nationalism", "Ethnic pride" or whatsoever designed to combat the destructive consequences of universal racism and cultural imperialism on African people. Without taking the risk of plugging into unnecessary and unproductive debates, the main challenge for the Afrocentrist is to provide a different interpretation of the African realities, a new visualization of the continent's past and present so that to liberate the minds of the ignorant or miseducated masses, what Tsehloane Keto categorized as the "intellectual prisoners of blind universal history" when he declares, "in arguing the case for an Africa-centered perspective of history we also liberate the unwitting intellectual prisoners of 'blind universal history' by informing them that, what they worship as universal history 'is... as much a product of the mind of the historian who wrote it as it is the product of the actions of the people who actually lived it'”' (Tsehloane, 1989). He thereby acknowledges that the traditional academia of western universal discourses of history is no longer sustainable. Afrocentricity deals primarily with self-determination and African agency and is a Pan-African point of view for the study of culture, philosophy, and history (Gates \& Henry \& Kwame, 2005). The Afrocentrist seeks to uncover and use codes, paradigms, symbols, motifs, myths, and circles of discussion that reinforce the centrality of African ideals and values as a valid frame of reference for acquiring and examining data. Such a method appears to go beyond western history to re-valorize the African place in the interpretation of Africans, continental and diasporan (Asante, 1990). The Senegalese Anthropologist, Physicist and historian Professor Cheikh Anta Diop is seen today as the initiator of Afrocentricity. He had elaborated the most in-depth and cross-disciplined research of his time on the painstaking question of the "existence of an African Civilization". He was the first to claim "Ancient Egyptian Civilization" as an inalienable part of the black African cultural heritage based on consistent shreds of evidence from archeological, linguistics, physics, anthropological and historical sources, and went far based on the monogenetic theory of professor Leaky to legitimate the "African origin of humanity". In his two master's pieces $<$ the African Origin of Civilization: Myth or Reality>, and <Civilization or Barbarism: An Authentic Anthropology $>$, Professor Diop expounded in details his main findings. These outcomes briefly summed up below pathed a way to what is seen today as "The Afrocentric Theory":

(a) The human race first came into existence in Africa in the region of the sources of the Nile.

(b) The earliest human beings (Homo sapiens sapiens) on earth were ethnically homogeneous and Negroid (Blacks).

(c) The earliest human beings' population spread out from Africa in the region of the sources of the Nile reaching other regions of the earth by only two routes: the Nile valley and the Sahara. In the Nile valley, this spread took place from the south in a northerly direction, in a progressive movement, between the Upper Paleolithic and the protohistoric periods.

(d) The population of Egypt was Negro (black) since the pre-dynastic period, a conclusion contradicting the theory that the Negro element spread to Egypt in later times. 
(e) Present-day Egyptians, particularly in Upper Egypt, belonged to the same blood-group, B, as the population of West Africa, and not to Group A, which was characteristic of the white race. (Diop went on to state that a conclusive anthropological study would also include 61 Ancient Civilizations of Africa osteological measurements and the study of blood-groups.)

(f) The Ancient Egyptian Civilization is to be counted among the assets of Black Africa. The Black world is the very initiator of the "Western (Greco-Roman) Civilization" flaunted before our eyes today. The Pythagorean mathematics, the theory of the four elements of Thales of Miletus, Epicurean materialism, Platonic idealism, Judaism, Islam, and modern science are rooted in Egyptian cosmogony and science.

(g) Professor Diop considered that the science of Egyptology, a product of imperialism, had much to answer for in denying all the facts to which he had just referred (above).

These findings had owned Africa's history with a new chapter in the United Nations General History of Africa Volume 2 (UNESCO International Committee for the Drafting of General History of Africa, 27-83, Edited by Joseph Kizerbo). The works of Cheikh Anta Diop, together with the contribution of African Africanists such a Joseph Kizerbo, Kwame Nkrumah, etc. have provided Africa's history with a new narrative in modern academia and should be the foundation of any in-depth a genuine study of Africa in modern days.

\section{Africology /Africanology: Afrocentric Appraisals of "African Phenomena" from across the Atlantic}

The Diasporan Africans of the Americas are among the first to rise scholastic debates on "African Studies by Africans for Africans". With pioneers such as W.E.B Du Bois, Marcus Garvey, etc. the necessity of an African philosophy, Science and Humanities that primarily serve the African Community was already voiced out. These pioneering ideas have inspired what is known today in the United States' academic circle as "Africology". Meanwhile, in mainland Africa, the rising anti-colonialists and pan-Africanist figures such as Kwame Nkrumah, Jomo Kenyatta, Julius Nyerere, etc. gave a new vision to the African ideological orientation. However, the works of Cheikh Anta Diop threw in a new dynamism within the African scholarship circle, triggered the rising of new schools of thought, those working to revise the educational system to extirpate what they consider as footprints of the ancient colonizers. The idea is for this new generation of African scholars of the mainland to reevaluate educational materials, teaching contents as well as the languages used so that to better reflect the African diversities and redefine the African identity, and therefore come out with education reforms that will accelerate African emancipation. This new school known as "Africanology" encompasses all the knowledge and core issues that make Africa an interesting area of research and studies in the fields of humanities and social sciences (Diallo, 2019). Africology in the Americas and Africanology in mainland Africa are Afrocentric embodiments of a unique "African Phenomena" from both sides of the Atlantic.

\subsection{Africology}

\section{Historical Background}

America is one of the earliest post-colonial societies where Scholastic debates on African Studies led by Africans have emerged. Debates that followed the "Black political and academic revolution" of the $20^{\text {th }}$ century in the United States of America. At the frontline of political activism were prominent figures such as W.E.B Du Bois. Martin Luther King, Malcolm X, etc. while the academic revolution drew its energy from its organic link with the people who were experiencing the persistent white racial domination in the classrooms. These were not theorists who had studied at some elite graduate school; most were undergraduate students or graduate students who were the first-generation college students in their families. They could not afford to "mess up" and yet they knew that they would be "messed up" if they took into their psychological systems the white racism that was being taught to them as if it were universal knowledge (Asante, 2015). The term "Black Studies" has ever since been coined out of this political and academic climate of the 1960s and the immediate academic aim was to create the opportunity for "a black perspective" in the American academy in social sciences, arts, and humanities. Several names emerged to describe the course of study and group of subjects under the umbrella of "Black Studies." Among the more popular names were "Afro American Studies" as in the UCLA Center for Afro American Studies; "Africana Studies" as in the Cornell University Department of Africana Studies; "African American Studies" as in the Temple University Department of African American Studies; "Africa World Studies" as in the Miami University "Africa World Studies" program; "African Diaspora Studies" as in the Ph.D. program at UC Berkeley; and "Africology" as in the Department of Africology at the University of Wisconsin at Milwaukee. A few departments, such as Ohio State University and California State University, Long Beach, retain the title of "Black Studies". Increasingly, and for critical reasons, the term "Africology" has gained recognition as a name and objective of our intellectual pursuit. However, there is no doubt that the puzzle in nomenclature still underpinning this field of study in the U.S academia reflects some real concerns. The problem with the expression "Black Studies" for example was that it sounded more racial, political and confrontational as opposed to "White". The term "Black" despite having strong cultural and ethnic connotation, still sounds exclusive in today's context as not all Africans are Blacks nor all Blacks are Africans. So, the expression "Black Studies" is problematic for some. It was also paradoxical for many whites 
Americans of the 60's-70's as never before "Black" and "Studies" has been used in the same term. Therefore, some U.S institutions opted for "African American Studies / Afro American Studies / Diaspora Studies". But here again, comes the problem of geographical coverage from the perspective of Area Studies as "African-American", "Afro-American" or "African-Diaspora" emphasizes the experience of African people out of mainland Africa. In these cases, the question of "culture" and "ethnicity" becomes even vaguer as it is hard to define a "diasporan culture" for example. The term "Africana" seemed to have brought answers to political, racial, geographical and even ethnic shortcomings displayed by other terminologies as it globally embraces the African realities and experiences in the world. The first "Africana Studies" department was formed after the Willard Straight Hall takeover at Cornell University, an Ivy League university located in Ithaca, New York. More precisely, in 1969, Cornell established its "Africana Studies and Research Center", one of the first such black studies programs in the Ivy League (Crawford, 2005). The African-American historian and emeritus professor, Robert L. Harris, offers a comprehensive definition of that field of study in <The Black Studies Reader> as follow: "Africana Studies is the multidisciplinary analysis of the lives and thought of people of African ancestry on the African continent and throughout the world. It embraces Africa, Afro-America, and the Caribbean, but does not confine itself to those three geographical areas. Africana studies examine people of African ancestry wherever they may be found-for example, in Central and South America, Asia, and the Pacific Islands. Its primary means of organization are racial and cultural. Many of the themes of Africana studies are derived from the historical position of African peoples in relation to Western societies and in the dynamics of slavery, oppression, colonization, imperialism, emancipation, self-determination, liberation, and socioeconomic and political development."(Robert L., 2004) This definition furthers up the gap between "Africana Studies" and "African studies", as its focus combines Africa and the African diaspora into a concept of single "African experience" with a Pan-African perspective. However, the expressions "Africana Studies" despite being large enough to embrace the African experiences on a global scope, seems not to be rooted enough in discipline criteria as defined by philosophy, methods, and orientation to data. For prof. Asante, "It had become fashionable to speak of Black Studies or Africana Studies as a field of study with numerous disciplines contributing to the study of African people (...) Africology was being used to signal that there was no longer a field, but a discipline of study", for, "Africology as the Afrocentric study of African phenomena was more than an aggregation of courses about African people”. The term Africology despite been coined initially in 1980 in its initial expression "Afrology" in the book Afrocentricity of prof. Asante was later refined as "Africology" by the University of Wisconsin-Milwaukee, one of the earliest American institution to approved the creation of the Center for Afro-American Culture since May 1968 and that was renamed in 1994 as the Department of Africology, a term coined by long-time department chair Dr. Winston Van Horne. In June 2008, the department was approved for a $\mathrm{PhD}$ program by the University Of Wisconsin Board Of Regents, and the first doctoral students began the $\mathrm{PhD}$ program in the fall of 2010. Study abroad programs that take students to Ghana, Ethiopia, etc. (Source: University of Wisconsin-Milwaukee web page).

\section{Present Day Significance}

Nelson has discussed the ontological base of Africology from the 1960s and evaluated the academic and intellectual connection with traditional disciplines of modern academia. From this point, he has set the scenario for uncovering the rationale and significance for Africology being acknowledged as a holistic discipline by stating, an appropriate paradigm for Africology must also combine self-knowledge and self-realization with social action. In contrast to the parochial, self-limiting practices of traditional disciplines, Africology must move its boundaries beyond the borders of academia and begin to register a concerted impact on the broader community. Africology must symbolize not only the search for a new discipline but a new community of political activists. ... As a discipline, Africology must also develop multiple avenues for communicating its accomplishments to the outside world (Nelson, 1989). Many academic journals dedicated to African Studies have been launched in the United States following the black scholarship movement. Such as The Black Scholar ( 1969), Afro-Americans in New York Life and History (since 1976), The Journal of African Civilizations (1979), International Journal of Africana Studies (1975), Africana - Journal of Ideas on Africa and the Diaspora, Electronic Journal of Africana Bibliography, Africana Online: Journal of the Africana Center for Cultural Literacy and Research, Nka Journal of Contemporary African Art. Africology: The Journal of Pan African Studies (since 1987) etc. 


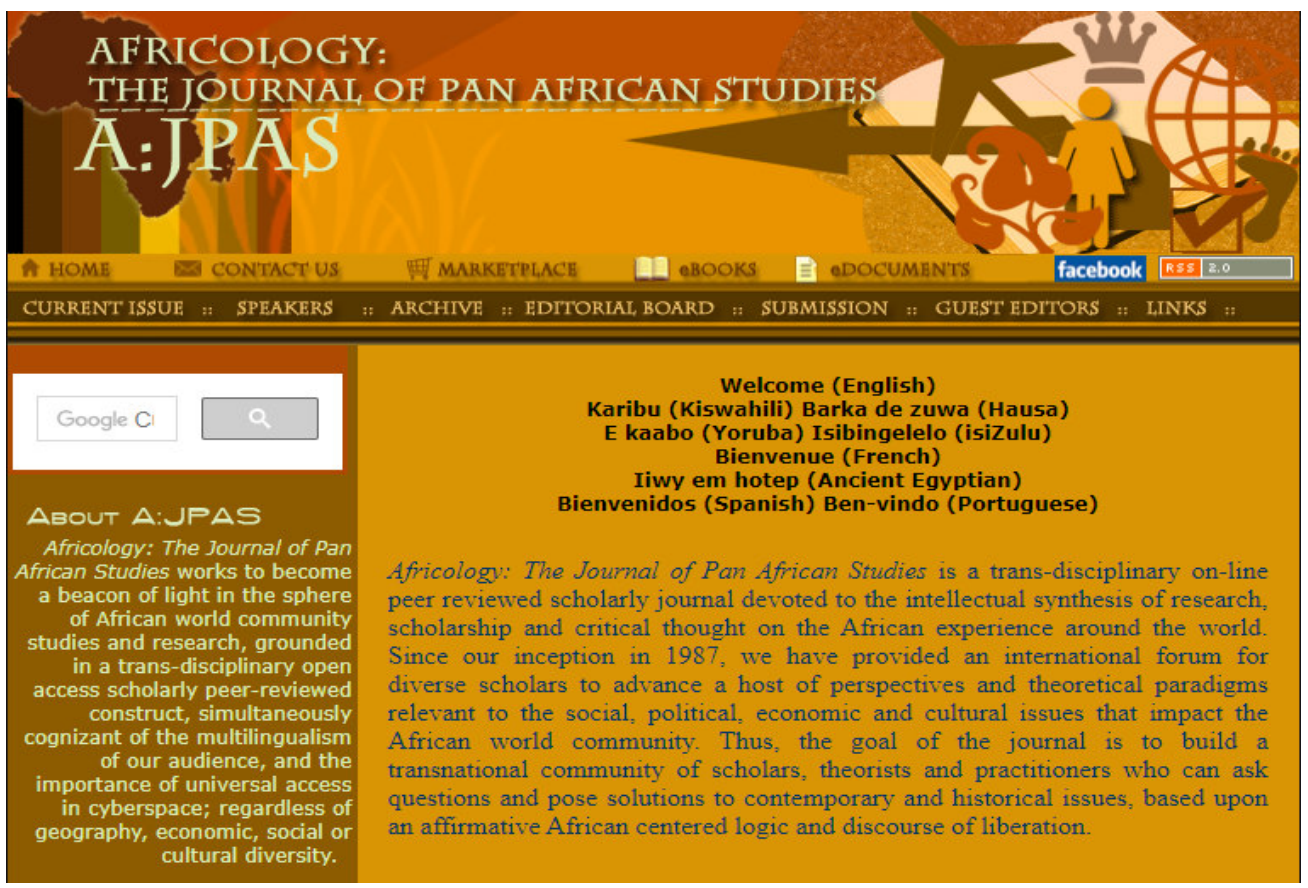

Figure. Africology: The Journal of Pan African Studies (since 1987)

One of the main challenges in the discipline of Africology today is the common mindsets of its scholars and the consensus on what is essential for the discipline. As pointed out by James It will be essential for Africologists to stand in the vanguard for the advancement of Africology as a discipline; this will illustrate the transformation from traditional disciplines to a holistic body of knowledge. Yet, there are those scholars who will not be willing to make this transformation and may find themselves outside the discipline and dependent on traditional fields of study. Perhaps there will emerge a new and growing constituency of scholars who will be committed to making a scholastic contribution to the advancement of humanity. The Afrocentric scholar will have to accept the challenge of using theory and practice in pursuit of truth, knowledge, and reality. (James, 2004)

\subsection{Africanology}

\section{A Mainland Appraisal of the "African Phenomena"}

What I understand by Africanology is merely the Afrocentric study of the "African phenomena" from a mainland standpoint. The "African phenomena" here is to be understood as the comprehensive and unique experience undergone by African people throughout space and time. African history is as much the product of that experience as is today's cultural development of African societies. The "African phenomena" is comparable to a gigantic Baobab tree which roots lie under the mainland soil, its trunk standing up above the continent of Africa and its branches, leaves, and fruits expanding all over the world wherever Africans might be found. If the idea of Afrocentricity is to reposition the African Being at the center of his or her existence, then Ancient Egypt remains the umbilical cord of life that makes that existence possible and meaningful. In short, Afrocentricity is meaningless without the linkage of black Africa to Ancient Egypt. Prof. Asante himself, a leading theorist of Afrocentricity acknowledged this crude but undeniable reality when he wrote: "Fundamental to this project is the belief that Cheikh Anta Diop was correct to argue that until Africans dare to connect Ancient Egypt to the rest of Africa there could be no true interpretation of African history (...).Diop understood the significance of examining the classical civilizations of Africa as a prelude to any discourse on anything African. Separating the study of African culture or civilizations by the Atlantic Ocean is a peculiar saline demarcation that does not exist in any real sense. Thus, to speak of a black Atlantic makes no real intellectual sense when you assume that Brazil, Venezuela, Nicaragua, Jamaica and Panama do not have anything to do with Africans in England or the United States. Indeed, all Africans on both sides of the Atlantic are inextricably joined by a common experience and a common cultural response, however tailored the response is to specific histories" (Asante, 2015). Although joined by "common experience" and common "Cultural response", there is no doubt that histories have got specificities and that the response at a certain extent has been "tailored". Africology and Africanology reflect such specificities from both sides of the Atlantic. Africology was initiated in an American context, fueled by African experiences in American society, and ever since its creation has been hosted by American institutions. Even though teachers and students from the mainland have contributed to its development and expansion, Africology remains an Americanized concept and sees the African problem with an Americanized mind. While African in Americas were experiencing Racism, social injustices, segregation, institutionalized discrimination, unfair civil rights, etc., the struggle on the 
mainland was focused on colonialism, self-determination, unfair economic practices, exploitation, etc. this was two different orientation of the same struggle for freedom that requires adequate contextualization. In $<\mathrm{Neo-}$ Colonialism, the Last Stage of Imperialism>, Kwame Nkrumah show a clear vision of the mainland struggle: "In place of colonialism, as the main instrument of imperialism, we have today neo-colonialism . . . [which] like colonialism, is an attempt to export the social conflicts of the capitalist countries. . The result of neo-colonialism is that foreign capital is used for the exploitation rather than for the development of the less developed parts of the world. Investment, under neo-colonialism, increases, rather than decreases, the gap between the rich and the poor countries of the world. The struggle against neo-colonialism is not aimed at excluding the capital of the developed world from operating in less developed countries. It is aimed at preventing the financial power of the developed countries being used in such a way as to impoverish the less developed" (Nkrumah, 1966). In that declaration, Nkrumah not only shows a clear understanding of African countries' main challenges but pathed a way forward that shaped the main historical response of mainland Africa to western imperialism. Though he was inspired by the brothers of the other side of the Atlantic such as W.E.B. Dubois, Marcus Garvey, and others diasporan Africans, Nkrumah was most preoccupied to tackle the most urgent issues of the continent, such as the "ethnic division" and the "balkanization of Africa", etc. He thereby proposed the concept of "African Unity" and the formation of a single "African State". These premium solutions were cornerstones of a genuine Africanology that primarily focus on the mainland experience from a mainland perspective with a pan-African horizon. Among its contributions, Nkrumah openly decried the norms of White Supremacy and Euro-centrism imposed by British textbooks and cultural institutions, settled down important cultural institutions such as the Ghana Museum (1957), the Nkrumah Institute of African Studies in 1962 (Haizel, 1992), the Ghana Film Corporation in 1964 (George P., 1992), etc. but most importantly, he influenced the creation of the Organization of African Unity (OAU), the ancestor of the today's African Union (AU) that is continuously working for the autonomy and self-determination of African people on a Pan-African scope. Following the same pan African vision, many other mainland Africanists such as Jomo Kenyatta, Joseph Ki-Zerbo, Julius Nyerere, etc. were among the prominent African Africanists who brought irrefutable contribution from the mainland. Among them, Cheikh Anta Diop rose the debate at an unprecedented level of "self-cognition" and "collective-consciousness" of the African being throughout humans' history and civilization. Professor Cheikh Anta Diop was the first African to articulate so powerfully the necessity of Ancient Egypt's linkage with Black Africa. Such clarity, on the part of the late Senegalese scholar, made him (alongside W. E. B. Du Bois) the greatest intellectual of the 20th century. When Diop died in 1986 he had already become the single most important historian of ancient Africa and consequently the patron of a new historiography that would elevate the writing of African history to another level of Afrocentricity (Keita, 2001). Insofar, professor Cheikh Anta Diop declared that “...foreign intellectuals, who challenge our intentions and accuse us of all kinds of hidden motives or ridiculous ideas, proceeded any differently? When they explain their own historical past or study their languages that seems normal. Yet, when an African does likewise to help reconstruct the national personality of his people, distorted by colonialism, that is considered backward or alarming (...) Our investigations have convinced us that the West has not been calm enough and objective enough to teach us our history correctly, without crude falsifications. (...) In a word, we must restore the historical consciousness of the African peoples and reconquer a Promethean consciousness.... define the image of a modern Africa reconciled with its past and preparing for its future."(Diop, 1974)

Several renowned Africanists from African origin of colonial and post-colonial eras have been working hard to provide a vibrant response to the global "misperception of Africa" by the outside world (include America), their voices and writings have shaped the mainstream ideologies of the continent. These ideologies constitute the backbones of an authentic Africanology, a fresh paradigm that intends to primarily address the geopolitical concerns of the continent through a self-centered socio-cultural and historical lens. Below is a un-exhaustive list of such notable Africanists whose thoughts, actions and beliefs have (and should) guided the next generations of young Africans ready to stand up and defend the continent's civilization and pride under the umbrella of Africanology. 


\begin{tabular}{|c|c|c|}
\hline Africanists & Personality \& Main Ideologies & Works and Publications \\
\hline Kwame Nkrumah & $\begin{array}{l}\text { Thinker, socialist, politician and revolutionary. } \\
\text { He was the first Prime Minister and President of } \\
\text { Ghana, having led the Gold Coast to independence } \\
\text { from Britain in 1957. Nkrumah was a founding } \\
\text { member of the Organization of African Unity that } \\
\text { later became the African Union and he was a } \\
\text { winner of the Lenin Peace Prize in 1962. His main } \\
\text { ideology Nkrumaism is a pan- } \\
\text { African socialist theory that aims to adapt } \\
\text { Marxist-Leninist theory to the social context of } \\
\text { the African continent. Nkrumah defined his belief } \\
\text { system as the ideology of a New Africa, } \\
\text { independent and free from imperialism, organized } \\
\text { on a continental scale, founded upon the } \\
\text { conception of one and united Africa, drawing its } \\
\text { strength from modern science and technology and } \\
\text { the traditional African belief that the free } \\
\text { development of each is the condition for the free } \\
\text { development of all. Over his lifetime, Nkrumah } \\
\text { was awarded honorary doctorates by many } \\
\text { universities including Lincoln University } \\
\text { (U.S), Moscow State University (USSR), Cairo } \\
\text { University (Egypt), Jagiellonian } \\
\text { University (Poland) } \\
\text { University (East Germany). }\end{array}$ & $\begin{array}{l}\text { - Ghana: The Autobiography of } \\
\text { Kwame Nkrumah (1957). } \\
\text { - Africa Must Unite (1963). } \\
\text { - African Personality (1963) } \\
\text { - Neo-Colonialism, the Last Stage } \\
\text { of Imperialism (1965) } \\
\text { - Axioms of Kwame } \\
\text { Nkrumah (1967). } \\
\text { - African } \\
\text { Revisited (1967) } \\
\text { - Voice from Conakry (1967) } \\
\text { - Dark Days in Ghana (1968) } \\
\text { - Handbook of Revolutionary } \\
\text { Warfare (1968) - first } \\
\text { introduction of Pan-African pellet } \\
\text { compass. } \\
\text { - Consciencism: Philosophy and } \\
\text { Ideology for } \\
\text { Colonisation (1970). } \\
\text { - Class Struggle in Africa (1970). } \\
\text { - The Struggle Continues (1973). } \\
\text { - I Speak of Freedom (1973). } \\
\text { - Revolutionary Path (1973). }\end{array}$ \\
\hline $\begin{array}{c}\text { Nelson Rolihlahla } \\
\text { Mandela }\end{array}$ & $\begin{array}{l}\text { Anti-apartheid revolutionary, political leader, and } \\
\text { philanthropist who served as President of South } \\
\text { Africa from } 1994 \text { to } 1999 \text { as the first black head of } \\
\text { state and the first elected in a fully } \\
\text { representative democratic election. } \\
\text { was considered both as "the father of the } \\
\text { nation" and "the founding father of democracy" in } \\
\text { S. A. His government focused on dismantling the } \\
\text { legacy of apartheid by tackling institutionalized } \\
\text { racism and fostering racial reconciliation. His } \\
\text { political development was strongly influenced by } \\
\text { his legal training and practice, in particular, his } \\
\text { hope to achieve change, not through violence but } \\
\text { "legal revolution". He sought to target symbols of } \\
\text { white supremacy and racist oppression rather than } \\
\text { white people as individuals and was anxious not to } \\
\text { inaugurate a race war in South Africa. Mandela } \\
\text { advocated the ultimate establishment of a classless } \\
\text { society, openly opposed to capitalism, private land- } \\
\text { ownership and the power of big money. Mandela } \\
\text { was influenced by Marxism, and during the } \\
\text { revolution, he advocated scientific socialism. } \\
\text { Throughout his life, Mandela was given over } 250 \\
\text { awards, accolades, prizes, honorary degrees and } \\
\text { citizenship in recognition of his political } \\
\text { achievements. Among his awards were the Nobel } \\
\text { Peace Prize, the US Presidential Medal of } \\
\text { Freedom, the Soviet Union's Lenin Peace Prize, } \\
\text { and the Libyan Al-Gaddafi International Prize for } \\
\text { Human Rights. }\end{array}$ & 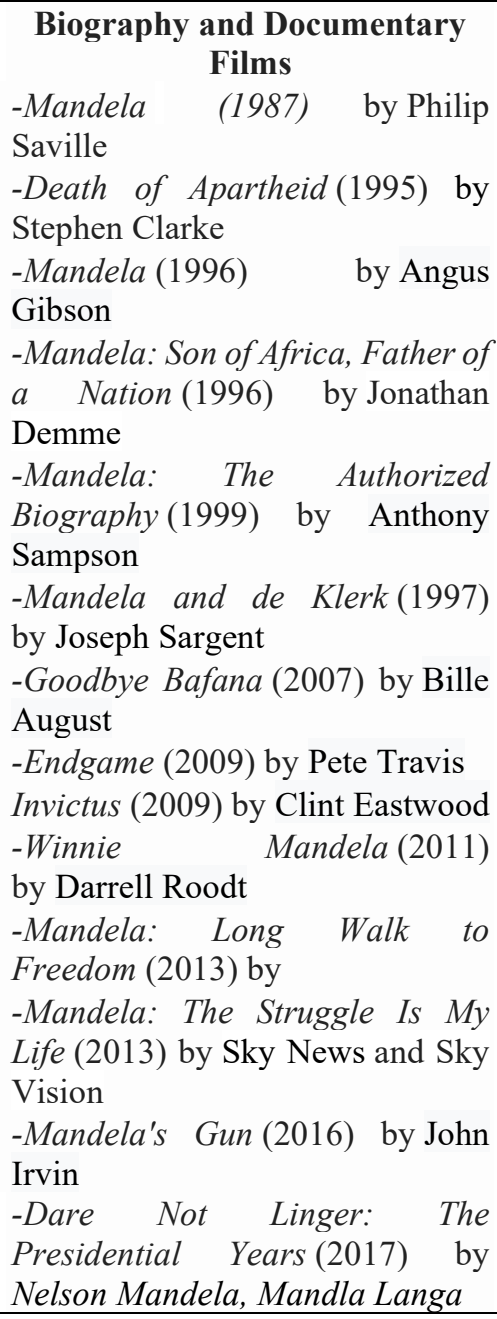 \\
\hline
\end{tabular}




\begin{tabular}{|c|c|c|}
\hline Africanists & Personality \& Main Ideologies & Works and Publications \\
\hline 986 Senegal & $\begin{array}{l}\text { Historian, anthropologist, physicist, } \\
\text { and politician who studied the human race's } \\
\text { origins and pre-colonial African culture. } \\
\text { sometimes referred to as an Afrocentrist, Diopian } \\
\text { thought, as it is called, is paradigmatic to } \\
\text { Afrocentricity. Diop argued that African peoples } \\
\text { shared certain commonalities, including language } \\
\text { roots and other cultural elements like regicide, } \\
\text { circumcision, totems, etc. These, he held, formed } \\
\text { part of a tapestry that laid the basis for African } \\
\text { cultural unity, which could assist in throwing off } \\
\text { colonialism. His cultural theory attempted to show } \\
\text { that Egypt was part of the African environment as } \\
\text { opposed to incorporating it into Mediterranean or } \\
\text { Middle Eastern venues. Diop argues that only a } \\
\text { united and federated African state will be able to } \\
\text { overcome underdevelopment. He proposed that a } \\
\text { single African language be used across the } \\
\text { continent for official, educational, and cultural } \\
\text { purposes. Diop's work has posed important } \\
\text { questions about the cultural bias inherent in } \\
\text { scientific research. Cheikh Anta Diop University } \\
\text { in Dakar, Senegal, is named after him. }\end{array}$ & $\begin{array}{l}\text { - Nations nègres et culture (1954) } \\
\text { - L'unité culturelle de l'Afrique } \\
\text { noire : domaines du patriarcat et } \\
\text { du matriarcat dans l'antiquité } \\
\text { Classique (1959) } \\
\text { - L'Afrique noire précoloniale. } \\
\text { Etude comparée des systèmes } \\
\text { politiques et sociaux de l'Europe et } \\
\text { de l'Afrique noire, de l'antiquité à } \\
\text { la formation des états modernes } \\
\text { (1960) } \\
\text { - Antériorité des civilisations } \\
\text { nègres : mythe ou vérité } \\
\text { historique? (1967) } \\
\text { - The African Origin of } \\
\text { Civilization: } \\
\text { Reality (1974) Myth } \\
\text { - Parenté génétique de l'égyptien } \\
\text { pharaonique et des langues négro- } \\
\text { africaines : processus de } \\
\text { sémitisation (1977) } \\
\text { - Black Africa: the economic and } \\
\text { culturalbasis for afederated state. } \\
\text { (1978) - Civilization or Barbarism : an } \\
\text { authentic anthropology (1981) }\end{array}$ \\
\hline 1930-2013 Nigeria & 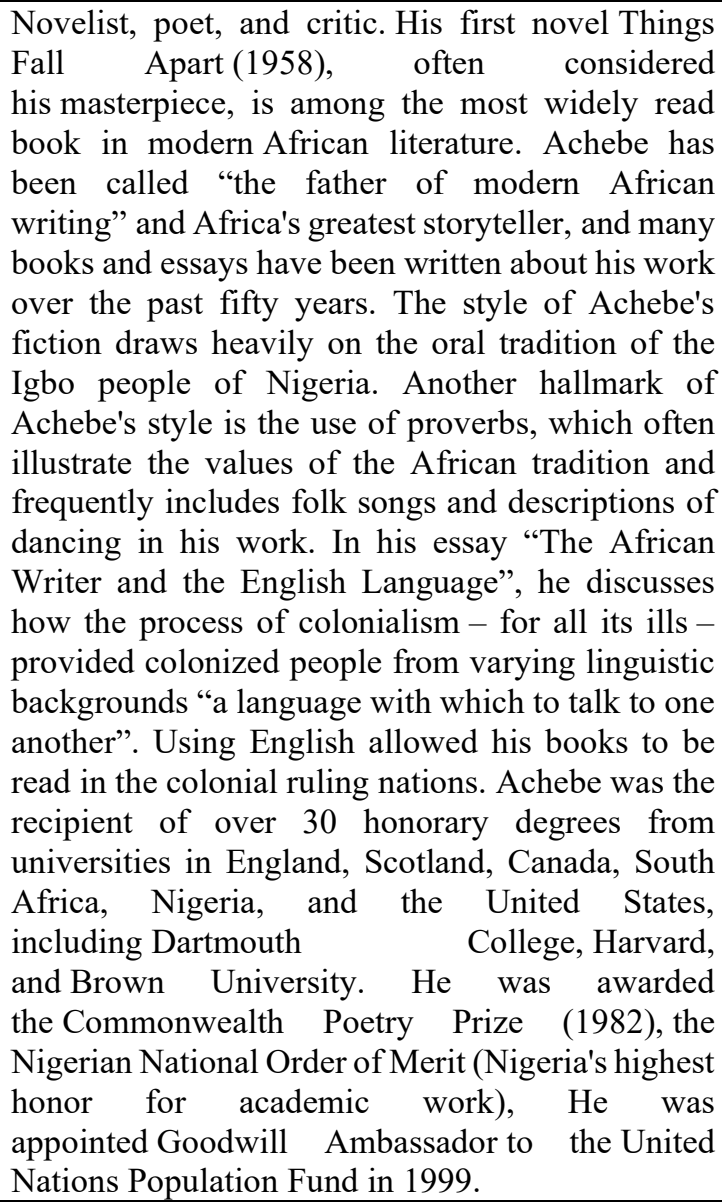 & $\begin{array}{l}\text { - Marriage Is a Private } \\
\text { Affair (1952) } \\
\text { - Dead Men's Path (1953) } \\
\text { - Things Fall Apart (1958). } \\
\text { - No Longer at Ease (1960) } \\
\text { - Arrow of God (1964) } \\
\text { - A Man of the People (1966). } \\
\text { - Chike and the River (1966) } \\
\text { - Civil Peace (1971) } \\
\text { - How the Leopard Got His } \\
\text { Claws (1972) } \\
\text { - The Flute (1975) } \\
\text { - The Drum (1978) } \\
\text { - Don't Let Him Die: An Anthology } \\
\text { of Memorial Poems (1978) } \\
\text { - The Trouble with Nigeria (1984) } \\
\text { - African Short Stories (1985) } \\
\text { - Anthills of the Savannah (1987) } \\
\text { - Hopes and Impediments (1988) } \\
\text { - The Heinemann Book of } \\
\text { Contemporary African Short } \\
\text { Stories (1992) } \\
\text { - Another Africa (1998) }\end{array}$ \\
\hline
\end{tabular}




\begin{tabular}{|c|c|c|}
\hline & Personality \& Main Ideologies & Works and Publications \\
\hline & $\begin{array}{l}\text { Anti-colonial activist pan-Africanist and politician } \\
\text { who governed Kenya as its Prime Minister from } \\
1963 \text { to } 1964 \text { and then as its first President from } \\
1964 \text { to his death in } 1978 \text {. He was the country's first } \\
\text { indigenous head of government and played a } \\
\text { significant role in the transformation of Kenya } \\
\text { from a colony of the British Empire into an } \\
\text { independent republic and seen as the } \\
\text { founding "Father of the Nation". Ideologically } \\
\text { an African nationalist and conservative, Kenyatta } \\
\text { has also been described as a talented orator, author, } \\
\text { and editor. }\end{array}$ & $\begin{array}{l}\text {-Facing Mount Kenya (1938) } \\
\text { - My People of Kikuyu and the Life } \\
\text { of Chief Wangombe } 1944 \\
\text { - Kenya: The Land of Conflict } \\
\text { (1944) } \\
\text { - Suffering Without Bitterness } \\
\text { (1968) } \\
\text {-The Challenge of Uhuru: The } \\
\text { Progress of Kenya, } 1968 \text { to } 1970 \\
\text { (1971) }\end{array}$ \\
\hline & $\begin{array}{l}\text { Anti-colonial activist, politician, and political } \\
\text { theorist. He gained recognition for the successful } \\
\text { merger between Tanganyika and Zanzibar, and for } \\
\text { leaving Tanzania as a united and stable } \\
\text { state. Ideologically he promoted a political } \\
\text { philosophy known as Ujamaa, andy', } \\
\text { Swahili word that means 'extended family', } \\
\text { 'brotherhood' or 'socialism'; as a political concept it } \\
\text { asserts that a person becomes a person through the } \\
\text { people or community. The spirit of 'others' or } \\
\text { 'community' bringing units of families together, } \\
\text { and fostering cohesion, love, and service. For much } \\
\text { of his life, he was a prolific writer and speaker, } \\
\text { leaving much material behind espousing his } \\
\text { ideology. }\end{array}$ & $\begin{array}{l}\text {-Freedom and Unity (Uhuru na } \\
\text { Umoja): A Selection from Writings } \\
\text { \& Speeches, 1952-1965 (1967) } \\
\text {-Freedom and Socialism (Uhuru } \\
\text { na Ujama): A Selection from } \\
\text { Writings \& Speeches, 1965- } \\
1967 \text { (1968) } \\
\text {-Freedom and Development } \\
\text { (Uhuru Na Maendeleo): A } \\
\text { Selection from the Writings \& } \\
\text { Speeches, 1968-1973 (1974) } \\
\text {-Ujamaa- Essays on } \\
\text { Socialism (1977) } \\
\text {-Crusade for Liberation (1979) }\end{array}$ \\
\hline $\begin{array}{c}\text { 1922-2006 } \\
\text { Burkinafaso }\end{array}$ & $\begin{array}{l}\text { Historian, politician, and writer recognized as one } \\
\text { of Africa's foremost thinkers. Professor of African } \\
\text { History at the University of Ouagadougou. } \\
\text { Socialist and an advocate of African independence } \\
\text { and unity. His conviction on education led him to } \\
\text { found in } 1980 \text { the Centre for African Development } \\
\text { Studies (CEDA) that has this goal "on ne } \\
\text { developpe pas, on se developpe" ("we don't } \\
\text { develop, we develop ourselves"). His } \\
\text { endogenous development is a practice that lets } \\
\text { native farmers use their own ideas and traditions } \\
\text { alongside new technology. It incorporates the ideas } \\
\text { and knowledge of indigenous cultures rather than } \\
\text { disregarding them. }\end{array}$ & $\begin{array}{l}\text { - Le Monde africain noir (1964) } \\
\text { - Histoire de l'Afrique noire } \\
\text { (1972) } \\
\text { - Histoire générale de l'Afrique } \\
\text { (1991) } \\
\text { - A quand l'Afrique, co-authored } \\
\text { with René Holenstein (2003) } \\
\text { - Afrique Noire, co-authored } \\
\text { with Didier Ruef (2005) }\end{array}$ \\
\hline $\begin{array}{l}\text { 1932-2001 } \\
\text { Cameroon }\end{array}$ & $\begin{array}{l}\text { Essayist, chronicler and novelist governed by one } \\
\text { obsession: the quest for the dignity of African } \\
\text { people. Influenced by the currents of rebellion } \\
\text { sweeping Africa in the wake of World War II. By } \\
\text { the early 1950s, Beti had turned to writing as a } \\
\text { vehicle of protest. From beginning to end, Beti's } \\
\text { work was informed by two principles. In terms of } \\
\text { style, he was a realist. Thematically, Beti's work is } \\
\text { unified by an unwavering commitment to } \\
\text { combatting colonialism, both overt and covert. } \\
\text { Beti's aim always, even in his harsh criticism of } \\
\text { Cameroon's independence government, was to } \\
\text { strengthen African autonomy and prosperity. }\end{array}$ & $\begin{array}{l}\text { - Ville cruelle (1955) } \\
\text { - Le pauvre Christ de Bomba } \\
\text { (1956) } \\
\text { - Mission terminée (1957) } \\
\text { - Le roi miraculé : chronique des } \\
\text { Essazam (1958) } \\
\text { - Main basse sur le Cameroun } \\
\text { (1972) } \\
\text {-Les procès du Cameroun (1972) } \\
\text { - Perpétue et l'habitude du } \\
\text { Malheur (1974) } \\
\text { - Dictionnaire de la négritude } \\
\text { (1989) } \\
\text { - La France contre l'Afrique : } \\
\text { Retour au Cameroun (1993) }\end{array}$ \\
\hline
\end{tabular}




\begin{tabular}{|c|c|c|}
\hline Africanists & Personality \& Main Ideologies & Works and Publications \\
\hline $\begin{array}{c}\text { Amadou } \\
\text { Hampâté Bâ }\end{array}$ & $\begin{array}{l}\text { Malian writer, historian and ethnologist. He was } \\
\text { an influential figure in twentieth-century African } \\
\text { literature and cultural heritage. He was a champion } \\
\text { of Africa's oral tradition and traditional } \\
\text { knowledge and is remembered for the saying: } \\
\text { "whenever an old man dies, it is as though a library } \\
\text { were burning down." In 1942, he was appointed to } \\
\text { the Institut Français d'Afrique Noire (IFAN-the } \\
\text { French Institute of Black Africa) in Dakar. At } \\
\text { IFAN, he made ethnological surveys and collected } \\
\text { traditions. For } 15 \text { years he devoted himself to } \\
\text { research, which would later lead to the publication } \\
\text { of his work L'Empire peul de Macina (The Fula } \\
\text { Empire of Macina). With Mali's independence in } \\
1960 \text {, Bâ founded the Institute of Human Sciences } \\
\text { in Bamako, and represented his country at the } \\
\text { UNESCO general conferences. In 1962, he was } \\
\text { elected to UNESCO's executive council, and in } \\
\text { 1966 he helped establish a unified system for the } \\
\text { transcription of African languages. }\end{array}$ & $\begin{array}{l}\text { (1955)_The Fula Empire of } \\
\text { Macina } \\
\text { (1957)_The Life and Education } \\
\text { of Tierno Bokar, the Wise Man of } \\
\text { Bandiagara } \\
\text { A Spirit of Tolerance: The } \\
\text { Inspiring Life of Tierno } \\
\text { Bokar (2008) } \\
\text { Kaïdara, récit initiatique } \\
\text { peul(1969) } \\
\text { (1973)_The Strange Destiny of } \\
\text { Wangrin, } \\
\text { (1974) The Brightness ofthe Great } \\
\text { Star } \\
\text { (1976)_Jesus, as Viewed by a } \\
\text { Muslim } \\
\text { (1977)_Little Bodiel (a Fula } \\
\text { tale) and a prose version of } \\
\text { Kaïdara } \\
\text { (1985) -Njeddo Dewal, Mother } \\
\text { of Calamity } \\
\text { (1987)_A Handful of Dust, } \\
\text { Malian Stories } \\
\text { (1988)-Kaydara: } \\
\text { Mysterious Journey } \\
\text { (1991)_Amkoullel, the Fula Child } \\
\text { (1994)_Yes, My Commander }\end{array}$ \\
\hline $\begin{array}{l}\text { Congo } \\
1936-\end{array}$ & $\begin{array}{l}\text { Théophile Obenga holds the Ph.D. in Letters, Arts } \\
\text { and Humanities. He is a member of the African } \\
\text { Society of Culture (Présence Africaine). He } \\
\text { contributed as part of the United Nations } \\
\text { Educational and Scientific Cultural Organization } \\
\text { (UNESCO) program, to the writing of the General } \\
\text { History of Africa and the Scientific and Cultural } \\
\text { History of Humanity. He was, until the end of } \\
\text { 1991, Director General of the Centre International } \\
\text { des Civilisations Bantu (CICIBA) in Libreville, } \\
\text { Gabon. From January } 28 \text { to February 3, 1974 at } \\
\text { Cairo, Egypt, Théophile Obenga accompanied } \\
\text { Cheikh Anta Diop as Africa's representatives to the } \\
\text { UNESCO symposium on "The Peopling of Ancient } \\
\text { Egypt and the Deciphering of the Meroitic Script." } \\
\text { This meeting remains one of the single most } \\
\text { important and famous defenses of African } \\
\text { intellectual on historical integrity of Africa in the } \\
\text { modern era. He is the Director and Chief Editor of } \\
\text { the journal Ankh. Obenga has advocated a number } \\
\text { of fringe ideas such as a "Negro- } \\
\text { Egyptian" language family (négro-égyptien), } \\
\text { which includes all languages of Africa apart from } \\
\text { Berber, Semitic and Khoisan, an approach that he } \\
\text { shares with Cheikh Anta Diop. }\end{array}$ & 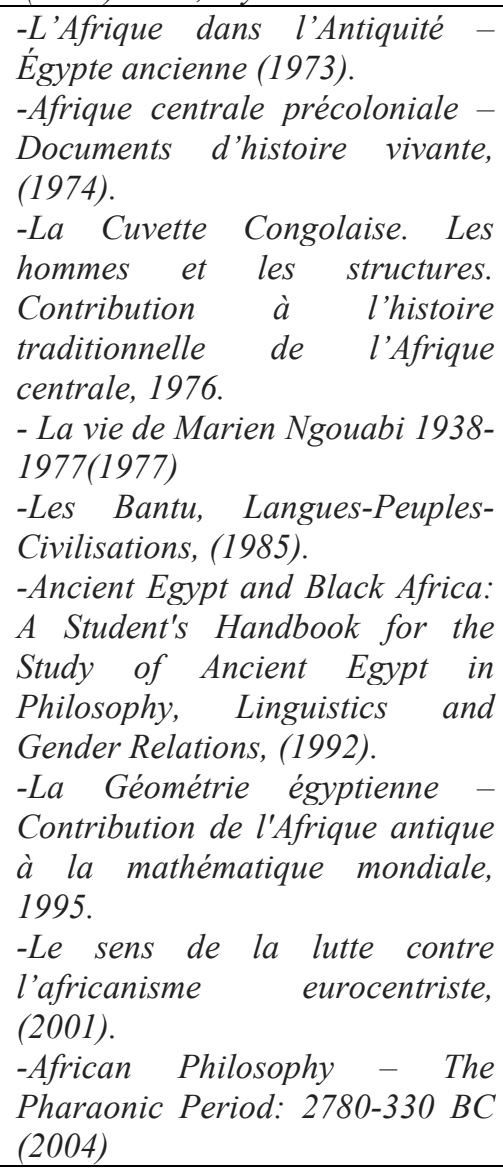 \\
\hline
\end{tabular}




\section{Africanology in Modern Academia}

From an academic viewpoint, a key focus of the discipline should be to sort out epistemological and critical approaches, theories and methods that insert Africa-centered ideologies, knowledge, and references. In fact, "Africanology" should primarily aim at providing the most correct understanding of Africa's cultures and societies as experienced by African people themselves. In some parts of Africa such as west-Africa (Senegal), African scholarship is already integrating the concept to better reflect the idea of an "African perception of Africa". They believe that Africa's history, societies, and cultures should be written by African people themselves and that there is a pressure need to rethink the historical, socio-cultural, and politico-economic perception of Africa in contemporary academia (Yoro, 2019). In some respects, “Africanology” should go beyond providing a global or specific knowledge of Africa through traditional Social science methodologies, it should be a response to global attitudes about African people and their historical contributions; it should seek to correct what it sees as prejudices and misconceptions perpetuated by the racist philosophical underpinnings of western academic disciplines as they developed during Europe's early renaissance and that is still dominating the modern academia. In this $21^{\text {st }}$ century where powers' interests on the continent are guided by their appetite for natural resources and market-driven ambitions, the study of Africa for some of these powers has been resumed to measure the number of profits and global influence that one can draw out of the continent regardless of the overall side effects generated. To understand this, perhaps it suffices to take the western discourses on African history as examples. From an African point of view, the capitalist motives of colonial powers led to the "balkanization" of the continent regardless of ethnicity, languages or cultural specificities of the people concerned, leading to unprecedented destruction of African cultures and societies, resulting to an unbalanced and underdeveloped African society as we see today. But when studying African history from a European perspective, one can still be tempted to believe that colonization brought civilization and enlightenment to Africans, to such an extent that some former colonial powers of today shamelessly claim the so-called "colonial debt" through mechanisms such as currency manipulation, debt-trap diplomacy, military intervention, etc. in their former colonies. Steven Erlanger the chief diplomatic correspondent in Europe for The New York Times in an article published the12 September 2011 stated that "France's relationship with its former African colonies is known as 'Françafrique', which is commonly mocked as 'France à fric', since 'fric' is slang for money" (Steven Erlanger, 2011). He was on the same wave with Tony Chafer who asserted earlier that "Since political independence (of African countries), France has maintained a privileged sphere of influence-the so-called 'pré-carré'-in sub-Saharan Africa, based on a series of family-like ties with its former colonies (Tony Chafer, 2005)." These "family-like" paternalist ties have created a heavy dependency of African countries vis-à-vis of their former colonizers and exposed them to further exploitation today known as neocolonialism. Professor Yoro Diallo believes that "Europe has dominated, acculturated, assimilated and exploited Africa for centuries. Despite such a long period of domination, the academic work of Europeans on Africa has remained peppered with clichés, prejudices and unbridled paternalism, often distorting historical realities and misinterpreting essential elements of African cultures" (Yoro, 2019). As goes the popular quote of the Nigerian writer Chinua Achebe: "Until the lions have their own historians, the history of the hunt will always glorify the hunter." In a word, the new school of "Africanology" through innovative methodologies (of collection, orientation and treatment of data) should work to preserve the unalienable legacies of African history and civilization that still suffer from controversies, denials and imperialist attempt of alienation. "Africanologists" should make sure that sets of normative beliefs and values that African people have created and adapted over the course of history for non-epistemic reasons are thoroughly dug down and understood by the world.

\section{Sinafricology: A Chinese Africology/Africanology}

The recent years have seen a rising number of institutions (Research Centers, Academic Journals, etc.) in China devoted to African Studies, especially after the 2006 FOCAC summit. The China-African Institute is the last in date established following President Xi Jinping's important measures to strengthen China-Africa cooperation at the Beijing summit of the Forum on China-Africa Cooperation FOCAC 2018 and inaugurated on April 9, 2019, in Beijing. Chinese President Xi Jinping sent a congratulatory letter to the establishment of the Chinese Academy of African studies. Representatives of Chinese and African government departments, academic institutions, think tanks, social celebrities and African nationals in China attended the conference along with 350 people (Source: People's Daily). These emerging institutions reflect a growing interest for the Chinese to deepen the study of Africa. "African Studies' do exist because of the existence of 'African problems', the research, thinking and knowledge accumulation during the process of solving that problem constitutes the practical basis of 'African Studies", once said the Chinese scholar Professor Liu Hongwu, Changjiang Scholar of the Chinese Ministry of Education (Liu Hongwu, 2019). The problem with the traditional African Studies in Chinese academia is how the Chinese scholarship approaches the discipline. How to tackle the "African Problem" out of the western prism still remain the main concern. Moreover, there is an absolute need for a solid theoretical foundation to achieve a comprehensive and in-depth discipline that will critically examine Africa's social sciences and humanities from an unbiased stance. The idea of Chinese Africology/Africanology is an attempt to solve this problem from its roots. 
We firmly believe that no one understands the so-called "African Problems" better than African people themselves, and no other nation is better positioned than African people to bring a durable solution to "African Problems". Just as the Chinese themselves, having undergone ups and downs to achieve the today's Chinese rejuvenation, only Chinese solutions have brought an end to the long-lasting cultural, economic and political crisis experienced by the country from Mao Zedong to Deng Xiao Ping, as well as the ongoing health crisis (COVID-19) under Xi Dingping. No one can understand China better than the Chinese themselves, and no people could solve Chinese related problems better than the Chinese people. This is true for other places including Africa. Only an Africancentered discipline could provide an in-depth understanding of Africa in Chinese academia. However, it is logical to think that in China's context, some specificities have to be taken into account, for example the language and cultural barriers as well as the government policies and priorities, etc. The concept "Sinafricology" embody such an ideal. While seeking an Afrocentric approach of African Studies in Chinese academia, "Sinafricology" should be flexible enough to encompass the "Chinese Characteristics" and guiding principles of China's education policies (Taling, 2019). It's an adaptation process of Africology/Africanology in the Chinese context that aims to provide the Chinese academia with a holistic Afrocentric approach of African Studies with Afrocentricity as a theoretical foundation. Professor Liu Hongwu, brilliantly classified the "Chinese Characteristics" of academic pursuit in three levels as follow: "The 'Chinese characteristics' of China's Study and understanding of Africa today (in Chinese Academia) can be divided into three different but interrelated levels, which need to support and promote each other. The first level is the general knowledge that comes from understanding and serves the communication between nations and peoples. (Such as the natural geography, countries and people, history and culture, customs and practices of Africa in comparison with the Chinese civilization and other general knowledge). The second level is dedicated to the theoretical framework and policy research on Africa's politics, economy, social culture and international relations in the service of practical China-Africa cooperation and exchanges. The third level is the African academic research in the general sense of 'social science development', highlighting its academic, ideological, universal and rational (approach)." According to Professor Liu, these Characteristics are basic requirements for the domestic development of contemporary Chinese social sciences and civilization to effectively overcome the hundred years' narrow and inert framework of "Sino-Western duality thinking" instilled into the Chinese academia, and so to help reconstruct a modern system of Chinese knowledge and discourses essential to achieve a fair and balanced platform of dialogue and exchange with the world. Therefore, a new approach of African Studies in Chinese Academia must be grounded on a solid theoretical foundation and should carry out methodical research on a well-defined knowledge content of Africa in comparison with (or in relation with) China within governments' policies frameworks.

"Sinafricology" so to speak must provide to its learners with "an Afrocentric approach of the African reality coupled with the Chinese characteristics". This could be achieved through a 5-layers's approach, namely Theoretical, Methodological, Content Knowledge, Institutional and Governmental.

\section{(a) Theoretical Layer}

A discipline of "Sinafricology" before all, must be a people-oriented discipline, for it is fundamental to change the perception and ways the Chinese scholarship perceive "Africa". Sino-Western dual perception of Africa heavily present in Chinese scholastic milieu must be undone in favor of the awareness and promotion of an existing "Africanology" of the Continent. In other words the African perception of Africa (as opposed to the westernized global view of Africa) should become a reality in the Chinese scholastic circle. Consequently, the discipline has to be propped up by African mainstream ideologies. Afrocentricity provides a comprehensive Africa-centered framework and a solid theoretical foundation for the discipline. In short, "Sinafricology" should theoretically be a sort of Afrocentric approach of the realities of the Mainland (as well as Diasporan) Africans. The discipline should support and promote the Pan African renaissance of the African consciousness under the motherland's umbrella. By embracing the study of Africa from such an Afrocentric perspective, the Chinese academia could upgrade China's African Studies at a new level of Afrocentricity and therefore operate the necessary paradigm shift needed in the current African Studies discipline conception.

\section{(b) Methodological Layer}

A proper methodology and approach of data should be demarcated. Africa is known to be the origin of Mankind, and together with China both are cradles of human civilizations with long histories and splendid cultures. However, the socio-cultural developments in both areas present huge divergences. China has since its early days shaped a centralized government and has preserved classics and writings, while Africa's history not only has been interrupted by several external factors but has been plugged by the constant migration of people all over the continent and beyond, this makes the study of Africa in Chinese academia very challenging when using traditional methodologies of Social Sciences. As a consequence, "Sinafricology" should come along with a new approach to data. Some of the existing Chinese institutions dealing with African Studies have adopted a general principle of dispatching researchers all over the continent with "firsthand data collections" as the primary goal. This is a necessary step, it is also the best way to get closer to the African realities of oral, socio-cultural, archeological, historical sources. Furthermore, a "System of Quotes and References" of African Studies and researches in Chinese 
academia should be standardized. Relevant Chinese institutions should adopt a "system of quoting and referencing" that prioritizes the African scholarship in order to better integrate "African ideologies", so as to avoid the "thinking of Africa without Africans" as did the Europeans. Nowadays, as China is moving firmly towards its rejuvenation, the western critics are spotting and voicing concerns on whether China is neo-colonizing Africa. A Sino-centralist conception of Africa by the Chinese scholarship will eventually lead to a Sino-centrism of Africa, which just as Eurocentrism, will hurt the continent and exposed its people to further bias clichés. Therefore "Sinafricology" must develop and promote a balanced and methodic approach of African Studies in Chinse Academia.

\section{(c) Content Knowledge's Layer}

"Sinafricology" should focus on the most pressing needs of the China-Africa fast-growing relationship, more precisely on the most urgent needs of the continent (infrastructure development, good governance, technological transfer, etc.). Its main object of study should be the "people of Africa" (their history, socio-cultural development, geopolitical concerns, socio-economic well-being, etc.) rather than the "the landmass and its resources" (geography, geology, topography, zoology, etc.). It is of capital importance to deepen the content knowledge the discipline by exploring and referring to the pioneering works of Africanists of African origin such as Kwame Nkrumah of Ghana, Nelson Rolihlahla Mandela of South Africa, Cheikh Anta Diop of Senegal, Chinua Achebe of Nigeria, Jomo Kenyatta of Kenya, Julius Nyerere of Tanzania, Joseph Ki-Zerbo of Burkina-Faso, Mongo Beti of Cameroon, Amadou Hampâté Bâ of Mali, Théophile Obenga of Congo, etc. The works (books, publications, speeches, etc.) and legacies of these renowned African Africanists should be translated in Chinese languages, inserted and promoted in the academic curriculum of "Sinafricology".

\section{(d) Institutional Layer}

Specialized institutions such as faculties at the university level dealing with the discipline (from undergraduate level) should be created. Dragging talents from traditional majors and field of study and convey them mid-way in "African Studies professionals" is not very realistic. Academic institutions have to create rooms for the discipline of "Sinafricology" to fabricate "Chinese Experts of Africa" from ground zero. Scholarly exchanges and strategic partnerships between Chinese and African institutions should also be established and promoted to melt these Chinese talents in African institutions, this will increase their knowledge and experience of Africa. Some wellknown and prominent Centers for African Studies located in Africa such as the Center for African Studies (University of Addis Ababa Ethiopia), Kwame Nkrumah Institute of African Studies (University of Ghana), Institute of African and Diaspora Studies (University of Lagos Nigeria), Institute of African Studies (University of Ibadan), Centre for African Studies (University of Cape Town, South Africa), etc. should be backbases for Chinese institutions dealing in African studies, and concrete cooperation between such African institutions and the Chinese ones should be established (co-research projects, students exchanges programs, academic visit or teaching of African scholars in Chinese institutions, ...).

\section{(e) Governmental Layer}

International cooperation frameworks between China and African countries as well as government policies should provide a guiding line for the discipline. Subjects of common interests between China and Africa such as the issues of climate change, terrorism, etc., the promotion of multilateralism, territorial integrity, sustainable development, win-win cooperation,...through initiatives such as One Belt One Road, the U.N Sustainable Development Goals 2030, the A.U Agenda 2063, etc. should be the driving forces of the political will and commitment to support and sponsored the discipline. Proper funding, sponsorship, and scholarship should be considered on this effect.

\section{Conclusion}

The recent decades' relationship and cooperation between China and African countries have grown in leaps and bounds. As Africa is growing and playing a much more important role in the world's global economy and geopolitics, there is a need for Africa's strategic partners like China to speed up the study of the continent and deepen the understanding of its people. However, an unbiased approach to the African reality remains a challenge in modern academia largely dominated by western ideologies. The "Chinese-Western duality view" of the world plugging the existing traditional African Studies in Chinese academia has led to the necessity of reinventing the field. We stick on the view that any consistent study of Africa has to take into account the ways African people see themselves and write their history in this multicultural world. This ideology is embodied in paradigms such as Africanology (mainland Africa) and Africology (Diasporan Africa), all enrooted on the central concept of Afrocentricity. The awareness, acknowledgment and integration of such existing paradigms in the Chinese academia will mark the beginning of a new area of African studies in Chinese academia, a paradigm shift from the traditional African Studies to an Afrocentric approach of Africa by the Chinese scholarship. That idea reflected in the concept "Sinafricology" also aims at taking into account China's characteristics of social sciences development all-in-one. Such a paradigm will engineer in the Chinese academia, a discipline of Common and shared interests for China and Africa and achieve a holistic perspective for the new generation of Chinese scholarship to understand the "African phenomena". 


\section{References}

Asante, M. K. (1987). The Afrocentric idea. Philadelphia, PA: Temple University Press, 125.

Banner-haley, C.P.; Walker, Clarence E. (2003). We Can't Go Home Again: An Argument about Afrocentrism. Journal of Southern History. 69 (3): 663-665.

Keto, C. Tsehloane (1989). The Africa centered perspective of history. Blackwood, NJ: K. A. Publications, 6.

Gates, Henry Louis, and Kwame Anthony A. (2005). Africana: The Encyclopedia of the African and AfricanAmerican Volume 1, Oxford University Press, 111.

Asante, M. K. (1990). Kemet, Afrocentricity, and knowledge. Trenton, NJ: Africa World Press, 6.

United Nation General History of Africa (Volume 2). UNESCO International Committee for the Drafting of General History of Africa, 27-83.

Yoro Diallo (2019), Africologie chinoise : Etudes africaines d'une perspective chinoise, Chine Magazine. https://www.chine-magazine.com/africologie-chinoise-etudes-africaines-dune-perspective-chinoise/

Crawford, Franklin (2005). "Africana Studies and Research Center is on the Ascendant". Cornell News Service. https://news.cornell.edu/stories/2005/05/africana-studies-and-research-center-ascendant.

Robert 1. Harris Jr (2004). "The Intellectual and Institutional Development of Africana Studies",(in Jacqueline Bobo, Cynthia Hudley, Claudine Michel (2004). The Black Studies Reader), Routledge, 15.

University of Wisconsin-Milwaukee, College of Letters \& Science, African and African Diaspora Studies. https://uwm.edu/african-diaspora-studies/africology-history/

Nelson, W. E. (1989). Africology: From social movement to academic discipline. Columbus, OH: Center for Research and Public Policy of the Ohio State University Black Studies Extension Center, 24-25.

Asante, M. K. (2015) The Pursuit of Africology: On the Creation and Sustaining of Black Studies. http://www.asante.net/articles/59/afrocentricity/

Kwame Nkrumah (1966). Neo-Colonialism: The Last Stage of Imperialism. International Publishers Co., Inc. (USA).

E. A. Haizel (1992), "Education in Ghana, 1951-1966", in Arhin (1992), The Life and Work of Kwame Nkrumah. George P. Hagan (1992). "Nkrumah's Cultural Policy", in Arhin (1992), The Life and Work of Kwame Nkrumah.

Cheikh Anta Diop (1974). The African Origin of Civilization: Myth or Reality. Lawrence Hill Books, 1-10.

Steven Erlanger (2011). "Rwandan Leader, in Paris, Seeks to Ease Tensions". The New York Times. https://www.nytimes.com/2011/09/13/world/africa/13africa.html

Tony Chafer (2005). "Chirac and 'la Françafrique': No Longer a Family Affair". Modern \& Contemporary France. 13: 7-23.

James L. Conyers (2004). The Evolution of Africology: An Afrocentric Appraisal. Journal of Black Studies (34), 640-651.

Liu Hongwu (2019). Introduction to African Studies. People's Publishing House, 5-6.

Taling Tene Rodrigue (2019). Building an African Knowledge System with "Chinese and African characteristics”. China Social Science Net. 大灵・德内・罗德里格, 建构容纳“中非特色”的非洲知识体系. 中国社会科学报. 2019 年 11 月 22 日

http://www.cssn.cn/gjgxx/gj_fzwt/201911/t20191122_5047110.html?COLLCC=244010411\&COLLCC=368792 0339 